\title{
Perspectives on the Teaching of Geometry: Teaching and Learning Methods
}

\author{
Hamdi Serin (Corresponding Author) \\ Ishik University, Iraq \\ E-mail: Hamdi.serin@ishik.edu.iq
}

Received: November 7, 2017

Accepted: December 28, 2017 Published: February 20, 2018

doi:10.5296/jet.v5i1.12115

URL: http://dx.doi.org/10.5296/jet.v5i1.12115

\begin{abstract}
Geometry, an important branch of Mathematics, has a place in education for the development of critical thinking and problem solving, furthermore, that geometrical shapes are parts of our lives as they appear almost everywhere, geometry is utilized in science and art as well. This paper defines geometry teaching and puts forth why it has been given an important place in teaching mathematics. The major issue the paper deals with is to facilitate teaching Geometry through employing same useful preaches.
\end{abstract}

Keywords: Geometry teaching, Approaches, Learner

\section{Defining Geometry Teaching}

Geometry, as one of the most important branches of Mathematics, has a very significant place in education. Most of the items that we mostly see and use in our environment are composed of geometrical shapes and objects. Utilizing these objects and shapes efficiently depends on understanding the relations among them. We also make use of geometrical thoughts in solving problems (like painting, lining-wall etc.), in defining the space and running our profession as well. Geometrical shapes and objects are a part of our jobs and works. Making effective use of these objects depends on defining them and understanding the relation between the object and its duty (Altun, 2004:217).

The subjects in geometry are the ones that firstly draw attention of the people. The requirement to divide a piece of surface properly gave birth to geometry which is the information of measurement of objects and shapes and expression by the numbers. That's why this course has direct place in people's daily lives (Fidan, 1986).

Geometry is area of study of mathematics dealing with shapes and space. This area of study has an important role in developing students' critical thinking and problem solving skills (Pesen, 2006). Students start to understand and express the world around them by means of geometry and they analyze and solve the problems. They can also express from the perspective of the shapes to understand the abstract symbols better. Within this context, they 
can understand the shapes around them and can set up connection between daily life and mathematics.

The first inspiration sources of the mathematics phenomenon are the nature and the life. It is more required and easier to relate its geometrical side of this phenomenon. What people have done on behalf of geometry is to see the existing and undeniable truths in the nature and to take these relations to the new truths and new relations by discovering the relations among them (Develi and Orbay, 2003). People make decisions in their works and jobs by depending on their information regarding geometric shapes and objects. Carpenters measure the angles for house building. Engineers decide on which angles will shape slope of a highway road. Gardeners plan the geographical formations and positions on which flowers are grown (MEB, 1999:1-3).

The following items can be among some reasons why geometry is given place in mathematics teaching at schools (Baykul, 2005:363).

1) Critical thinking and problem solving occupy an important role amongst mathematical studies at school. Geometry studies provide significant contribution to the skills of critical thinking and problem solving.

2) Geometry subjects give assistance in teaching other topics of the mathematics. For instance, geometry is utilized to gain the concepts regarding fraction and decimal numbers; rectangles, squares, areas and circles are mainly used to teach the techniques of the operations.

3) Geometry is one of the most important parts of the mathematics which is used in daily life. For example, the shapes of the rooms, buildings and shapes used for ornaments are geometric shapes

4) Geometry is a device which is used a lot in science and art as well. As an illustration, it can be said that architects and engineers use geometric shapes a lot; geometrical characteristics are used quite much in the physics and chemistry.

5) Geometry helps students gain much more awareness about the world in which they live and appreciate its value. For example, the shapes of crystals and the orbits of the space objects are geometric.

6) Geometry is a tool that will help students have fun and even make them love mathematics. For example, they can have enjoyable games with geometrical shapes through cutting, pasting, rotating, parallel displacement and symmetry. It is required that a person who will be in charge of teaching and training of students must have comprehensive knowledge of the subject and must know the growth and development of human closely.

Geometry is one of the primary courses which are difficult to learn and comprehend for students. It is a fact that the success level in geometry is low. As a result of this, mathematics and geometry is a nightmare for most of the students (Akin and Cancan, 2007) because mathematics is a system on its own. One of the reasons lying beneath this failure is that 
geometrical thinking skills of the students are lower than expected. Thus, different teaching methods must be applied to be able to improve these skills and to make the teaching much more efficient. Within this context, geometry needs a strong pedagogical approach besides deep knowledge to be able to provide an enjoyable and intellectual atmosphere for students. The role of teacher is to guide students to have a better and comfortable thinking rather than to force students to think in his/her own limits because in today's pedagogical view, knowing much or having deep knowledge of any subject is not of high importance; the way how teachers present or guide to get the information occupies more significance. Hence, according to new teaching approaches, it is required for teachers to try to understand the codes and perceptions of any students rather than expecting students to understand what is hidden in teacher's mind.

\section{Geometry Teaching and Learning Methods}

Geometry is basically divided into two categories as conceptual part and graphical part. Teaching these two categories require different approaches. The conceptual parts must be transformed into perception by visualization; that is to say by the graphical parts. As Duval mentioned that "their synergy is cognitively necessary for proficiency in geometry" (Duval, 1998). According to him, there are several approaches to the graphical parts, especially discussing, teaching and interpreting the diagrams: immediate perpetual approach referring to the interpretation of the diagrams; operative approach that is used to determine the sub-configurations for problem solving; discursive approach referring to the description of the problems given.

Fischbein (1993) also treats formal and content parts, in other words figural and conceptual, as two sides of a coin. In this sense, the teachers must focus on the both figural side and conceptual part with a specific care since the teachers will describe the geometrical objects and their relations to each other while figural part will refer to these abstract objects. As Berthelot stated, in traditional geometry teaching, the theoretical properties, [figural parts] are assimilated into graphics (Berthelot and Salin, 1998). In this method, students are expected to read any diagram or graphic only by looking and transform the data given by the diagram in their minds; this used to be nightmares of the students.

In modern teaching, geometry is supported by the technology besides making use of some parts of the traditional methods. For example, invariance was put forward by the Mathematician Felix Klein in 1872 who described geometry "as the study of the properties of a configuration that are invariant under a set of transformations ..... that [can be illustrated in] all angle theorems like Thales' theorem and triangles [for example the sum of all internal angles equals to $\left.180^{\circ}\right]^{\prime \prime}$ (as cited in Jones, 2002). For the invariance, the use of dynamic software like GeoGebra will be quite useful since students will be able to see any immediate change and the relations of the angles as whole (Jones, 2002).

Symmetry is another key term for teaching geometry. The conceptual part is illustrated the visualization process as aforesaid. Defining the equalities between the angles, such as symmetry in triangles, students must be given a perception about symmetry which can be 
illustrated by using Interactive Whiteboard. These boards are very useful to draw such items as it gives chances to save, to highlight, to use ruler and to zoom in and out (Jones, 2002).

Geometry has been seen as a subdomain of Mathematics throughout the history and even today in primary schools, geometry is given under Mathematics. As Jones uttered that it "is a wonderful area of mathematics to teach [and learn] .... It is open to many different approaches .... [Which] has a long history intimately connected with the development of mathematics" (Jones, 2002). In this sense, teaching and learning geometry somehow goes parallel with mathematics training and education.

Most studies have been conducted on the learning styles since 1940 and many learning styles have been developed. Guild, in his conversation with Brandt, has mentioned that there are three different learning styles.

The first one is the individual awareness. This one is in fact the view of all learning styles theories but some educators like Gregorc focuses on this comparing to the other ways.

The second one is curriculum design and implementation of it to the educational processes. When it is known that the individuals learn in different ways, multi-directional educational methods can be used. Kolb, McCarthy, Butler et al. are some of the researchers adopting this idea.

The last approach is diagnostic approach. Individuals' learning styles that can be counted as key elements are diagnosed and then they are matched with the materials and the education to be prepared for individual differences. Rita Dunn, Kenneth Dunn and Marie Carbo can be shown among those who adopt this approach (Brandt, 1990).

There are two different perspectives about how we get the information. The initial one is how we perceive the information and the latter is how we process the knowledge we perceive. Each of us comprehends the truths differently and place them in our mind with separate styles. We are aware of the truths by feeling or observing or thinking or by practicing etc. (McCarthy, 1987; Morris and McCarthy, 1990). 4MAT learning styles have been taken account because it is focused on the process and perception of the information on the basis of McCarthy's learning style. There are four types of learner in 4 MAT learning styles. McCarthy names tem as first type learners (semiotic learners), second type learners (analytic learners), third type learners (learners via common sense) and fourth type learners (dynamic learners). Basic characteristics of the individuals having these learning styles have been described below (McCarthy, 1982; McCarthy, 1987; McCarthy, 1990).

First type learners (semiotic learners) perceive the knowledge/information through the concrete experience and process it via reflecting observatory method. They identify their living and experiences with themselves. They learn the thoughts by listening and sharing. They are the thinkers who trust in their own experiences. They are very successful in analyzing direct experiences from different views. They give importance to comprehend the lowdown of they learn. They need individual caring. They seek for the answer for "Why?" 
Second type learners (analytic learners) perceive the knowledge/information through the abstract experience and process it via reflecting observatory method. They set up theories by combining observation with existed data. They need to know what specialist know. They learn via experiences and views by evaluating the accuracy of the information they face. They give importance to systematic thinking. They like details. They can abolish the problems through logic, reasoning and analysis. They reanalyze the phenomena when the conditions turn the things into an incomprehensible manner. They like conventional classes; the schools are ideal for such students. They seek for the answer for "What?"

Third type learners (learners via common sense) perceive the knowledge/information via abstract conceptualization method and process it via active experience. They focus on the result. They unify the theory and practice. They learn the theories by testing. They learn well through manual techniques. They are perfect in problem solving. They do not like being given the answers; they need the method to solve the problems on their own. They pay attention to the strategical thinking. They are the students who are directed to the skills. They make experiments and they forward an idea on these experiments. They want to know of the formulas. They seek for the answer for "How?"

Fourth type learners (dynamic learners) perceive the knowledge/information through the concrete experience and process it via active experience. They unify experience and practice. They learn via trial and error method. They have confidence in self-discovery. They are excited about new things; they like researching. They reach at the correct results in the situations in which logical conditions do not exist. They solve the problems by their intuitions. They like taking risk. They want to know what they can do with the objects and the formulas. They are impatient sometimes. School is a tedious place for such individuals. The schools cannot satisfy the needs of those individuals as they demand to be persuaded for their interest through different methods. They seek for the answer for "What if ...?"

It is very important to evaluate individuals' learning styles for the process of learning and teaching (Hein and Budny, 2000). The information which is obtained by the determination of students' learning styles is helpful to decide on the method to be employed (Akkoyunlu, 1995). As Babadoğan (2000) stated that if the learning styles of the individuals are determined, then it will be much easier to understand that how the persons learn and what type of teaching method will be applied. Hence, the teacher can formulate appropriate teaching environments both for himself/herself and for the students. There are many researches that matching teaching and learning styles affect the students' success (Scales, 2000). It is expected that if the teachers' pay required attention to the teaching strategies that will co-operate with the learning style of the students, students will be more successful.

Peker and Dede (2005) have analyzed the relationship between learning styles of mathematics teaching candidates and their attitudes towards geometry in their study. The results have shown that the candidates have different learning styles; they have mentioned that even if their learning styles do not affect their attitudes against geometry, learning styles are the factors which must be taken into consideration from secondary school to university, even to the in-service training. 
Trying to materialize the geometry subjects requiring abstract thinking skill by using the tools like ruler, pen, paper and etc. may not be enough to internalize and visualize the relevant concepts and the rules. Hence, it is necessary to provide learning the geometry subjects in a much more detailed way, to follow the new tendencies in the education technologies regarding the visualization of the abstract concepts and to make use of them appropriately.

\section{References}

Akın, Y., \& Cancan, M. (2007). Matematik Öğretiminde Problem Çözümüne Yönelik Öğrenci Görüşleri Analizi. Kazım Karabekir Eğitim Fakültesi Dergisi, 16, 374-390.

Akkoyunlu, B. (1995). Bilgi Teknolojilerinin Okullarda Kullanımı ve Öğretmenlerin Rolü. Hacettepe Üniversitesi Ĕgitim Fakültesi Dergisi, 11, 105-109.

Altun, M. (2004). Matematik Öğretimi. İstanbul: Alfa Yayıncılık.

Babadoğan, C. (2000). Öğretim Stili Odaklı Ders Tasarımı Geliştirme. Milli Eğitim Dergisi, $147,61-63$.

Baykul, Y. (2005). Illköğretimde Matematik Öğretimi. Ankara: Pegema Yayıncılık

Berthelot, R., \& Salin, M. H. (1998). The role of pupils' spatial knowledge in the elementary teaching of geometry. In C. Mammana \& V. Villani (Eds.), Perspectives on the Teaching of Geometry for The 21st Century (pp. 71-77). Dordrecht, The Netherlands: Kluwer.

Brandt, R. (1990). On Learning Styles: A Conversation with Pat Guild. Educational Leadership, 48(2), 10-13.

Develi, H. M., \& Orbay, K. (2003). İlköğretimde Niçin ve Nasıl Bir Geometri Öğretimi, Milli Eğitim Dergisi, 157, 115-122.

Duval, R. (1998). Geometry from a cognitive point of view. In C. Mammana \& V. Villani (Eds.), Perspectives on the Teaching of Geometry for The 21st Century (37-52). Dordrecht, The Netherlands: Kluwer.

Fidan, N. (1986). Okulda Öğrenme Ve Öğretme. Ankara: Kadığlu Matbaası

Fischbein, E. (1993). The theory of figural concepts. Educational Studies in Mathematics, 24(2), 139-162.

Hein, T. L., \& Budny, D. D. (2000). Styles and Types in Science and Engineering Education. Paper Presented at International Conference on Engineering and Computer Education, Sao Paulo, Brazil.

Jones, K. (2002). Issues in the Teaching and Learning of Geometry. In L. Haggarty (Eds), Aspects of Teaching Secondary Mathematics: perspectives on practice. (Chapter 8 pp. 121-139) London: Routledge Falmer.

McCarthy, B. (1982). Improving Staff Development through CBAM and 4MAT. Educational Leadership, 40(1), 20-25. 
McCarthy, B. (1987). The 4MAT System: Teaching to Learning Styles with Right/Left Mode Techniques. Barrington: Excel, Inc.

McCarthy, B. (1990). Using the 4MAT System to Bring Learning Styles to Schools. Educational Leadership, 48(2), 31-37.

MEB. (1999). İlköğretim Okulu Matematik Dersi Ö̆gretim Programı, Ankara: Kocaoluk Yayıncilik.

Morgan, H. (2010). Teaching with the Interactive Whiteboard: An Engaging Way To Provide Instruction. Focus on Elementary, 22(3), 3-7.

Peker, M., \& Dede, Y. (2005). Matematik öğretmeni adaylarının öğrenme stilleri ve geometri tutumlari arasindaki ilişki. Sakarya Üniversitesi Eğitim Fakültesi Dergisi, 10, 61 - 69.

Pesen, C. (2006). Matematik Öğretimi (3. Baskı). Ankara: Pegem yayıncılık.

Scales, A. Y. (2000). The Effect of Learning Style, Major, and Gender on Learning Computer- aided Drawing in an Introductory Engineering/Technical Graphics Course. Unpublished $\mathrm{PhD}$ thesis, North Carolina State University.

\section{Copyright Disclaimer}

Copyright reserved by the author(s).

This article is an open-access article distributed under the terms and conditions of the Creative Commons Attribution license (http://creativecommons.org/licenses/by/3.0/). 